\title{
PENGARUH HYPNOTEACHING DALAM CONTEXTUAL TEACHING AND LEARNING TERHADAP KEMAMPUAN KOMUNIKASI MATEMATIS
}

\section{Qomario}

STKIP Al Islam Tunas Bangsa

E-mail: qomario@stkipalitb.ac.id

\section{Info Artikel}

Sejarah Artikel:

Diterima 15 Oktober 2018

Direvisi 6 November 2018

Disetujui 30 November 2018

\section{Keywords:}

Hypnoteaching, CTL, Mathematical Communication

\begin{abstract}
This research is motivated by students' mathematical communication skills that are considered still low. This is because the use of learning models or methods is less varied, and the teacher has not linked the subject matter to the everyday context because in teaching only uses one learning source. The study aimed to find out whether there was an effect of the application of the Hypnoteaching method in Contextual Teaching and Learning (CTL) to the mathematical communication skills of fifth grade students of Elementary School 1 Sukarame. The research method used is Quasi Experimental (Quasy Experimental Design). The population in this research were all sixth grade students of Elementary School 1 Sukarame, amounting to 87 students. The sample in this study uses saturated sampling because the entire population is used as a sample. Students' mathematical communication skills were measured using a test consisting of 8 essay questions, with a reliability index of 0.707. Based on the results of normality, using the Liliefors test and homogeneity, using the Bartlett test, it was found that data from three samples were normally distributed and homogeneous. So that for testing hypotheses can be used Anava test one way with the same cell. Anova test results obtained obtained $F_{\text {count }}=$ 19.195, while the value of $F_{\text {table }}=3.105$, because $F_{\text {count }}>F t_{\text {able }}$ then $H_{0}$ is rejected which means that is a significant influence of Hypnoteaching method in CTL. When $H_{0}$ was rejected, it was carried out by a double compatibility test with the Schefee method, and from the three treatments it was concluded that the Hypnoteaching method in CTL was better than conventional Hypnoteaching learning methods and conventional learning methods.
\end{abstract}

\begin{abstract}
Abstrak
Penelitian ini dilatarbelakangi oleh kemampuan komunikasi matematis siswa yang dianggap masih rendah. Hal ini dikarenakan penggunaan model atau metode pembelajaran kurang bervariasi, dan guru belum mengubungkan materi pelajaran dengan konteks kehidupan sehari-hari, sebab mengajar hanya menggunakan satu sumber belajar saja. Tujuan dari penelitian ini adalah untuk mengetahui apakah terdapat pengaruh penerapan metode Hypnoteaching dalam Contextual Teaching and Learning (CTL) terhadap kemampuan komunikasi matematis siswa kelas V SD N 1 Sukarame. Metode penelitian yang digunakan adalah Eksperimental Semu (Quasy Eksperimental Design). Populasi penelitian ini adalah seluruh siswa kelas V SD N 1 Sukarame yang berjumlah 87 siswa. Sampel dalam penelitian ini menggunakan teknik sampling jenuh, karena seluruh populasi digunakan sebagai sampel. Kemampuan komunikasi matematis siswa diukur dengan menggunakan tes yang berjumlah 8 soal essay, dengan indeks reliabilitas 0,707. Berdasarkan hasil uji normalitas, menggunakan uji Liliefors dan homogenitas, menggunakan uji Bartlett, diperoleh data dari ketiga sampel tersebut berdistribusi normal dan homogen. Sehingga untuk pengujian hipotesis dapat digunakan uji Anava satu jalan dengan sel sama. Hasil perhitungan uji Anava diperoleh $F_{\text {hitung }}=19,195$, sedangkan nilai $\mathrm{F}_{\text {tabel }}=3,105$, karena $\mathrm{F}_{\text {hitung }}>\mathrm{F}_{\text {tabel }}$, maka $\mathrm{H}_{0}$ ditolak artinya bahwa terdapat pengaruh yang signifikan dari metode Hypnoteaching dalam CTL. Ketika $\mathrm{H}_{0}$ ditolak dilakukan uji komparansi ganda dengan metode Schefee', dan dari ketiga perlakuan tersebut disimpulkan bahwa metode Hypnoteaching dalam CTL lebih baik daripada metode pembelajaran Hypnoteaching konvensional dan metode pembelajaran konvensional.
\end{abstract}

(C) 2018 Universitas Muria Kudus 
PENGARUH HYPNOTEACHING DALAM CONTEXTUAL TEACHING AND LEARNING ... REFLEKSI EDUKATIKA : Jurnal Ilmiah Kependidikan, Nomor 9, Volume 1, Desember 2018, hlm. 46-55

\section{PENDAHULUAN}

Pendidikan merupakan kebutuhan yang harus dipenuhi dalam kehidupan. Pendidikan dilakukan oleh setiap manusia untuk meningkatkan kemampuan diri dan meningkatkan derajat serta martabat manusia. Melalui pendidikan, manusia dapat mengembangkan segala potensi yang ada dalam dirinya guna mencapai kesejahteraan hidup. Salah satu faktor yang sangat memengaruhi keberhasilan penyelenggaraan pendidikan adalah kemampuan pendidik dalam menyiapkan peserta didiknya melalui proses pembelajaran yang berlangsung. Pendidik merupakan sosok yang bertanggung jawab dalam mencerdasakan kehidupan peserta didik. Memiliki pengetahuan yang luas, keterampilan yang memadai dan kepribadian yang mulia merupakan hal yang diharapkan ada dalam diri setiap peserta didik.

Seorang pendidik mempunyai usaha dalam mendidik peserta didiknya agar tercapai suatu tujuan pendidikan. Jika seorang pendidik tidak ada usaha dan niat dalam memotivasi peserta didik dalam belajar, maka tujuan dari pembelajarannya tidak tercapai dengan baik. Pendidik yang kurang memiliki keterampilan yang baik, maka materi pelajaran yang disampaikan juga tidak akan dapat diterima dengan baik oleh peserta didiknya.

Hasil pra-penelitian memberikan informasi bahwa, secara umum kemampuan komunikasi matematis peserta didik kelas V SD $\mathrm{N} 1$ Sukarame Bandar Lampung rendah jika dibandingkan dengan Kriteria Ketuntasan Minimal (KKM) yang ditetapkan pada Mata Pelajaran matematika. Hal ini diduga bukan hanya kelemahan belajar peserta didik, tetapi juga penggunaan model, metode, pendekatan maupun strategi pembelajaran yang kurang tepat sehingga pembelajaran di kelas masih cenderung monoton.

Berdasarkan uraian tersebut di atas, kemampuan komunikasi matematis masih rendah, dapat dilihat pada Tabel 1 berikut yang diperoleh dari hasil belajar siswa Mata Pelajaran Matematika pada materi Bangun Datar kelas V SD N 1 Sukarame.

Tabel 1

Nilai Matematika Peserta Didik Kelas V Materi Bangun Datar

\begin{tabular}{cccccc}
\multicolumn{6}{c}{ Materi Bangun Datar } \\
\hline N & \multirow{2}{*}{ Kls } & \multicolumn{3}{c}{ Hasil Belajar (X) } & \multirow{2}{*}{ Jml } \\
\cline { 3 - 5 } $\mathbf{0}$ & & $\mathbf{X}<\mathbf{6 0}$ & $\mathbf{6 0} \leq \mathbf{X}<\mathbf{7 0}$ & $\mathbf{6 0} \leq \mathbf{X}<\mathbf{7 0}$ & \\
\hline 1 & V A & 8 & 11 & 10 & 29 \\
2 & V B & 9 & 9 & 11 & 29 \\
3 & V C & 9 & 12 & 8 & 29 \\
& Jml & 26 & 32 & 29 & 87 \\
\hline
\end{tabular}

Berdasarkan Tabel 1 tersebut, dapat diketahui bahwa, masih banyak peserta didik yang mendapat nilai di bawah KKM yakni 68 . Jika dihitung dalam persen, diperoleh kurang lebih $66,7 \%$ yang mendapat nilai dibawah KKM. Hasil wawancara tidak terstruktur dengan guru kelas V SD N 1 Sukarame yaitu Ibu Dra. Nirmala, beliau memberikan informasi bahwa "masih banyak peserta didik kelas V yang kurang berani bertanya dengan guru maupun dengan temannya terkait materi pelajaran yang sedang dipelajari. Selain itu, peserta didik kurang percaya diri untuk berkomunikasi dalam mengapresiasikan ide-ide matematis mereka dalam proses pembelajaran dan peserta didik juga belum mampu mengaitkan materi pelajaran sesuai dengan permasalahan yang ditemukan dalam kehidupan sehari-hari. Ketika menyelesaikan soal essay misalnya, peserta didik masih banyak yang belum mampu menyelesaikan model matematika secara sistematis maupun menyelesaikan dengan ide-ide atau bahasa matematis mereka sendiri, bahkan masih ada yang hanya menyalin pekerjaan teman ketika diberikan tugas".

Berdasarkan hasil wawancara tersebut, dapat disimpulkan masalah utama dalam pembelajaran matematika yaitu kurangnya kemampuan peserta didik dalam berkomunikasi secara dua arah. Hal ini dapat terjadi karena pengetahuan seorang guru terkait metode-metode pembelajaran yang baru masih kurang, karena metode pembelajaran yang dilakukan guru di dalam kelas cenderung monoton dan kurang bervariasi sehingga menyebabkan peserta didik tidak aktif dan kurang termotivasi mengikuti proses pembelajaran.

Masalah lain yang terlihat yaitu guru yang belum mengaitkan materi pelajaran dengan konteks kehidupan sehari-hari. Dalam hal ini, proses pembelajaran guru hanya mengandalkan satu sumber belajar saja atau penggunaan media pembelajaran yang kurang tepat. Sehingga, kemampuan peserta didik dalam mengkaitkan materi pelajaran dengan kehidupan sehari-hari juga masih kurang.

Kemampuan komunikasi matematis merupakan salah satu tujuan pembelajaran matematika dan menjadi salah satu standar kompetensi lulusan dalam bidang matematika. Melalui pembelajaran matematika, peserta didik diharapkan dapat mengapresiasikan gagasan matematis mereka menggunakan simbol, diagram, tabel, atau media lain untuk memperjelas keadaan atau masalah matematika yang sedang dipelajari. Pada umumnya, 
PENGARUH HYPNOTEACHING DALAM CONTEXTUAL TEACHING AND LEARNING ... REFLEKSI EDUKATIKA : Jurnal Ilmiah Kependidikan, Nomor 9, Volume 1, Desember 2018, hlm. 46-55

pembelajaran matematika yang dilakukan oleh guru kepada peserta didik bertujuan supaya peserta didik dapat mengerti dan menjawab soal yang diberikan oleh guru. Tetapi peserta didik tidak pernah atau jarang sekali diberikan penjelasan asal mula mereka mendapatkan jawaban tersebut. Sehingga, jika peserta didik menemukan masalah dalam bentuk model matematika yang berbeda dengan soal contoh dari guru, maka peserta didik akan merasa kesulitan untuk menyelesaikannya.

Menurut Buchori dalam Trianto (2008: 3), bahwa pendidikan yang baik adalah pendidikan yang tidak hanya menyiapkan para peserta didiknya untuk suatu profesi atau jabatan, tetapi untuk menyelesaikan masalah-masalah yang dihadapinya dalam kehidupan sehari-hari. Berbagai masalah pokok dalam pembelajaran pada pendidikan formal (sekolah) dewasa ini adalah masih rendahnya daya serap peserta didik dalam menerima materi pelajaran. Hal ini nampak pada rata-rata hasil belajar peserta didik yang senantiasa masih sangat memprihatinkan dan dapat diartikan bahwa pembelajaran masih berpusat pada guru, metode pembelajaran yang diterapkan guru kurang bervariasi dan tidak memberikan kesempatan peserta didik untuk berkembang secara mandiri melalui penemuan dan proses berpikirnya.

Pendidik seharusnya memiliki keterampilan khusus dalam menggunakan metode pembelajaran. Sebab, metode mengajar yang diterapkan dalam suatu pengajaran dikatakan efektif bila menghasilkan sesuatu sesuai dengan yang diharapkan atau dapat mencapai tujuan yang telah ditetapkan. Pada pembelajaran matematika, sebelum menerapkan metode pembelajaran harus menyusun strategi belajar-mengajar, sehingga dapat dipilih alat peraga atau media pembelajaran sebagai pendukung kegiatan belajar mengajar. Selain hal tersebut, pendidik harus mampu memotivasi atau memberikan sugesti kepada peserta didik agar pembelajaran matematika yang diperoleh dapat memberikan makna tersendiri bagi kehidupan mereka sehari-hari.

Metode pembelajaran yang berprinsip dengan menggunakan sugesti adalah metode Hypnoteaching. Secara harfiah, Hypnoteaching berasal dari kata hypnosis dan teaching. Hypnosis berarti menyugesti dan teaching yang berarti mengajar. Jadi dapat diartikan bahwa Hypnoteaching adalah usaha untuk memberikan sugesti atau motivasi kepada peserta didik agar dalam belajar mampu mengingat materi pelajaran yang telah diajarkan. Tujuan dari metode Hypnoteaching adalah mendorong guru dalam berkomunikasi secara efektif dengan peserta didik. Sebab, komunikasi yang baik antara guru dan peserta didik atau sebaliknya, mampu meningkatkan kualitas hasil pembelajaran.

Metode Hypnoteaching akan mengubah persepsi peserta didik terhadap pendidik yang mengajar, yakni bahwa pendidik menjadi pelindung mereka. Namun, persoalan saat ini adalah bagaimana menemukan cara yang terbaik untuk menyampaikan berbagai materi yang diajarkan sehingga peserta didik dapat menggunakan dan mengingat lebih lama materi yang telah diajarkan oleh pendidik. Bagaimana pendidik dapat berkomunikasi dengan peserta didik sehingga dapat mempelajari berbagai konsep materi dan cara mengaitkan dalam kehidupan nyata. Proses pembelajaran ini diperlukan sebuah keterkaitan pendekatan dalam pembelajaran kontekstual (Contextual Teaching and Learning) yang mampu membantu pendidik mengaitkan konteks mata pelajaran dengan situasi dunia nyata dan memotivasi peserta didik membuat hubungan antara pengetahuan dan penerapannya dalam kehidupan mereka. Pembelajaran dan pengajaran kontekstual melibatkan para peserta didik dalam aktivitas penting yang membantu mereka mengaitkan materi pelajaran dengan konteks kehidupan nyata yang mereka hadapi. Dalam kelas kontekstual, tugas guru adalah membantu peserta didik belajar dan guru mengelola kelas sebagai sebuah tim yang bekerja bersama untuk menemukan sesuatu yang baru bukan diperoleh hanya dari kata-kata seorang gurunya saja. Sehingga diharapkan peserta didik mampu meningkatkan kemampuan komunikasi matematisanya dalam proses belajar.

Hypnoteaching adalah salah satu pengembangan metode pembelajaran terbaru yang digunakan guru di sekolah. Pada awalnya, hipnoterapi hanya digunakan dalam bidang kesehatan. Namun, sejalan dengan perkembangannya, metode ini mulai diterapkan dalam bidang pendidikan, khususnya dalam proses pembelajaran. Hypnoteaching merupakan gabungan dari lima metode pembelajaran, yaitu quantum learning, accelerate learning, power teaching, Neuro-Linguistic Programming (NLP) dan hypnosis. Pembelajaran dengan metode hypnoteaching menekankan pada komunikasi alam bawah sadar siswa, baik yang dilakukan dalam kelas maupun di luar kelas dengan berbagai cara seperti sugesti dan imajinasi. Meskipun metode ini belum banyak digunakan 
PENGARUH HYPNOTEACHING DALAM CONTEXTUAL TEACHING AND LEARNING .. REFLEKSI EDUKATIKA : Jurnal Ilmiah Kependidikan, Nomor 9, Volume 1, Desember 2018, hlm. 46-55

oleh guru dalam proses pembelajaran, tetapi hypnoteaching telah terbukti efektif dalam mengoptimalkan proses pembelajaran di sekolah (Irwandi 2015).

Hakim (dalam Hasbullah dan Rahmawati, 2015) menambahkan bahwa hipnosis merupakan kondisi ketika seseorang mudah menerima saran, informasi, dan sugesti yang mampu mengubah seseorang dari hal yang kurang baik menjadi hal yang baik. Teknik menuju kondisi hypnosis sebenarnya telah digunakan oleh pengajarpengajar handal guna memudahkan murid untuk memahami dan mencerna setiap materi pembelajaran. Hypnoteaching menekankan pada komunikasi alam bawah sadar siswa, baik yang dilakukan dalam kelas maupun luar kelas.

Belajar matematika dengan metode Hypnoteaching diharapkan dapat memunculkan nilai-nilai positif peserta didik serta lingkungannya (termasuk guru dan teman), sehingga kemampuan komunikasi matematis peserta didik dapat ditingkatkan karena keberanian untuk mengapresiasikan ide-ide matematis serta pendapat mereka. Melalui metode Hypnoteaching dalam Contextual Teaching and Learning (CTL), diharapkan mampu memberikan pengaruh baik terhadap kemampuan komunikasi matematis peserta didik dan peserta didik dapat memahami makna dari belajar secara kontekstual di SDN 1 Sukarame Bandar Lampung karena metode ini sebelumnya belum pernah diterapkan di sekolah tersebut.

Berdasarkan beberapa penelitian, metode Hypnoteaching memberikan dampak positif terhadap suatu pembelajaran. Penelitian Rodli Abdul Latif dengan judul "Pengaruh metode Hypnoteaching dalam Contextual Teaching and Learning (CTL) terhadap Kemampuan Komunikasi dan Analisis Kritis Siswa Kelas XI IPA di SMA Negeri 5 Yogyakarta, menunjukkan bahwa metode Hypnoteaching dalam Contextual Teaching and Learning (CTL) berpengaruh terhadap kemampuan komunikasi dan analisis kritis siswa. Penelitian yang dilakukan oleh Prima Vidya Asteria dengan judul "Penerapan Metode Hypnoteaching Dalam Pembelajaran Bermain Peran Siswa Kelas V SDN Lidah Kulon IV Surabaya", menyimpulkan bahwa selama proses pembelajaran, suasana pembelajaran bermain peran di kelas akan lebih kondusif, peserta didik merasa penting, aman dan nyaman dengan penerapan metode Hypnoteaching. Selain itu, penelitian yang dilakukan oleh Rahmawatiningrum dengan judul Efektivitas Penggunaan metode Hypnoteaching dalam Pembelajaran Matematika Kelas IV SDIP H.
Soebandi Semarang, menyimpulkan bahwa terdapat perbedaan efektivitas pembelajaran yang signifikan antara penggunaan Metode Hypnoteaching dan Metode Konvensional pada pembelajaran matematika peserta didik. Begitu juga penelitian yang dilakukan oleh Priyanto yang berjudul "Penggunaan Metode Hypnoteaching Dalam Peningkatan Pembelajaran Matematika Tentang Pecahan Pada Siswa Kelas V SD Negeri Benerwetan Tahun Ajaran 2014/2015" menyimpulkan bahwa penggunaan metode hypnoteaching dapat meningkatkan proses dan hasil belajar matematika tentang pecahan siswa kelas V SD Negeri Benerwetan Tahun Ajaran 2014/2015. Hal ini memungkinkan Metode Hypnoteaching dapat diterapkan pada pembelajaran matematika di setiap jenjang pendidikan seperti SD, SMP atau SMA dengan mata pelajaran yang berbeda.

Berdasarkan penelitian yang relevan dan uraian latar belakang di atas, peneliti termotivasi untuk mengadakan penelitian dengan judul "Pengaruh Penerapan Metode Hypnoteaching dalam Contextual Teaching and Learning (CTL) Terhadap Kemampuan Komunikasi Matematis Siswa Kelas V SD Negeri 1 Sukarame”.

Metode Hypnoteaching merupakan perpaduan dua kata "hypnosis" yang berarti mensugesti dan "teaching" yang berarti mengajar. Jadi, dapat diartikan bahwa Hypnoteaching adalah usaha untuk menghipnosis atau mensugesti anak didik supaya menjadi lebih baik prestasinya. Hypnoteaching dapat dikatakan sebagai improvisasi (penyediaan) dari sebuah metode pembelajaran.

Menurut Novian Triwidia Jaya yang dikutip oleh Yustisia (2012:76), Hypnoteaching merupakan perpaduan pengajaran yang melibatkan pikiran bawah sadar dan pikiran sadar. Hypnoteaching, ini merupakan metode pembelajaran yang kreatif, unik, sekaligus imajinatif. Sebelum pelaksanaan pembelajaran, peserta didik sudah dikondisikan untuk belajar. Dengan demikian, peserta didik mengikuti pembelajaran dalam kondisi segar dan siap untuk menerima pelajaran.

Menurut Novian Triwidia Jaya, ada beberapa definisi hipnosis yang pernah diungkap yaitu; (a) Hipnosis merupakan teknik atau praktik dalam mempengaruhi orang lain untuk masuk dalam kondisi trance hipnosis, (b) hipnosis adalah suatu kondisi dimana perhatian menjadi sangat terpusat, sehingga daya terima saran meningkat sangat tinggi, (c) hipnosis merupakan seni komunikasi untuk mempengaruhi seseorang sehingga mengubah 
PENGARUH HYPNOTEACHING DALAM CONTEXTUAL TEACHING AND LEARNING ... REFLEKSI EDUKATIKA : Jurnal Ilmiah Kependidikan, Nomor 9, Volume 1, Desember 2018, hlm. 46-55

tingkat kesadarannya yang dapat dicapai dengan menurunkan gelombang otak dari Beta menjadi Alpha dan Theta, (d) hypnosis merupakan seni komunikasi untuk mengeksplorasi alam bawah sadar, (e) hypnosis adalah kondisi kesadaran yang meningkat.

Hypnoteaching merupakan perpaduan dari dua kata yaitu "hypnosis" yang berarti mensugesti dan "teaching" yang berarti mengajar. Sehingga dapat diartikan bahwa hypnoteaching adalah "menghipnosis/ mensugesti" siswa agar menjadi pintar dan melejitkan semua anak menjadi bintang. Hypnoteaching adalah salah satu strategi mengajar yang meningkatkan motivasi dan kualitas belajar siswa. Hypnoteaching juga bisa diartikan sebagai perpaduan pengajaran yang melibatkan pikiran sadar (Conscious Mind) dan pikiran bawah sadar (Sub Conscious Mind) (Salami 2017).

Jadi, Hypnoteaching dapat diartikan suatu metode yang dapat digunakan dalam proses pembelajaran dengan menggunakan bahasa sugestif atau motivasi kepada peserta didik, agar peserta didik dapat lebih fokus dan nyaman ketika proses pembelajaran berlangsung.

Langkah-langkah penggunaan metode hypnoteaching dalam pembelajaran matematika tentang pecahan sebagaimana dikemukakan oleh Hajar (dalam Priyono, dkk., 2015) adalah (a) niat dan motivasi; (b) pacing; (c) leading; (d) gunakan kata positif, kata-kata yang diberikan oleh pendidik baik langsung maupun tidak langsung sangat mempengaruhi kondisi psikis peserta didik; (e) berikan pujian; (f) modeling.

Di indonesia, matematika disebut dengan ilmu pasti dan ilmu hitung. Matematika secara umum ditegaskan sebagai penelitian pola dari struktur, perubahan, dan ruang; tak lebih resmi, orang mungkin mengatakan bahwa matematika adalah penelitian bilangan dan angka. Dalam pandangan formalis, matematika adalah pemeriksaan aksioma yang menegaskan struktur abstrak menggunakan logika simbolik dan notasi matematika (Kasmaja, 2016).

Dari sisi abstraksi matematika, Newman dalam Jackson (1992:755) melihat tiga ciri utama matematika, yaitu : 1) matematika disajikan dalam pola yang lebih ketat, 2) matematika berkembang dan digunakan luas daripada ilmuilmu lain, dan 3) matematika lebih terkonsentrasi pada konsep. Sedangkan matematika dalam sudut pandang Nasution (1982 : 12) istilah matematika berasal dari kata Yunani, mathein atau manthenein yang berarti mempelajari. Kata ini memiliki hubungan yang erat dengan kata
Sanskerta, medha atau widya yang memiliki arti kepandaian, ketahuan, atau inteligensia. Dalam bahasa belanda, matematika disebut dengan kata wiskunde yang berarti ilmu tentang belajar (hal ini sesuai dengan kata mathein pada matematika. Sedangkan orang Arab menyebut matematika dengan 'ilmu al-hisab' yang berarti ilmu hitung.

Contextual Teaching and Learning (CTL) menurut Suprijono (2009:78) merupakan konsep belajar yang membantu guru mengaitkan konten mata pelajaran dengan situasi dunia nyata dna mendorong peserta didik membuat hubungan antara pengetahuan yang dimilikinya dengan penerapannya dalam kehidupan sehari-hari. Pembelajaran kontekstual juga dikenal dengan experiental learning, real world education, active learning, dan learned centered instruction. Pembelajaran kontekstual memusatkan pada bagaimana peserta didik mengerti makna dari apa yang mereka pelajari, apa manfaatnya, dan bagaimana mereka mendemonstrasikannya.

Menurut Khakim dkk (2015), Pembelajaran Contextual Teaching and Learning merupakan suatu pola yang membantu guru di dalam pembelajaran untuk mengaitkan konten pelajaran dengan dunia nyata siswa sehingga siswa bisa menerapkan pengetahuannya dalam kehidupan sehari-hari.

Kemampuan komunikasi matematis adalah kemampuan siswa dalam menyampaikan ide matematika baik secara lisan maupun tulisan. Kemampuan komunikasi matematis peserta didik dapat dikembangkan melalui proses pembelajaran di sekolah, salah satunya adalah proses pembelajaran matematika. Hal ini terjadi karena salah satu unsur dari matematika adalah ilmu logika yang mampu mengembangkan kemampuan berpikir siswa (Hodiyanto, 2017).

Menurut Susanto $(2013 ; 213)$ Komunikasi merupakan keterampilan yang sangat penting dalam kehidupan manusia. Satu-satunya alat untuk dapat berhubungan dengan orang lain dilingkungannya ialah komunikasi, baik secara lisan maupun tulisan. Komunikasi secara umum dapat diartikan sebagai suatu cara untuk menyampaikan suatu pesan ke penerima pesan untuk memberitahu, pendapat, atau perilaku baik langsung secara lisan maupun tak langsung melalui media.

\section{METODE PENELITIAN}

Jenis penelitian yang digunakan pada penelitian ini adalah penelitian eksperimen semu atau Quasy Experimental Design. Desain ini mempunyai kelompok kontrol, tetapi tidak dapat berfungsi sepenuhnya untuk mengontrol 
variabel-variabel luar yang mempengaruhi pelaksanaan eksperimen (Sugiyono, 2011:114).

Dalam penelitian ini responden dikelompokkan menjadi tiga kelompok. Kelompok pertama adalah kelompok eksperimen, yaitu peserta didik yang mendapat pembelajaran matematika dengan metode Hypnoteaching dalam Contextual Teaching and Learning (CTL). Kelompok kedua adalah kelompok kontrol, yaitu peserta didik yang mendapat pembelajaran metematika dengan metode Hypnoteaching konvensional. Kelompok ketiga adalah kelompok kontrol dengan pembelajaran matematika menggunakan metode konvensional. Pelaksanaan eksperimen yang akan peneliti laksanakan dapat digambarkan pada tabel berikut ini

Tabel 2

Desain Penelitian

\begin{tabular}{cccc}
\hline & \multicolumn{3}{c}{ Metode Pembelajaran $(X)$} \\
\cline { 2 - 4 } & $\begin{array}{c}\text { Penerapan Metode } \\
\text { Hypnoteaching } \\
\text { dalam CTL }\left(\mathrm{X}_{1}\right)\end{array}$ & $\begin{array}{c}\text { Penerapan Metode } \\
\text { Hypnoteaching } \\
\text { Konvensional } \\
\left(\mathrm{X}_{2}\right)\end{array}$ & $\begin{array}{c}\text { Penerapan Metode } \\
\text { Konvensional }\left(\mathrm{X}_{3}\right)\end{array}$ \\
\hline $\begin{array}{c}\text { Kemampuan } \\
\text { Komunikasi } \\
\begin{array}{c}\text { Matematis } \\
(Y)\end{array}\end{array}$ & $\left(\mathrm{X}_{1} \mathrm{Y}\right)$ & $\left(\mathrm{X}_{2} \mathrm{Y}\right)$ & $\left(\mathrm{X}_{3} \mathrm{Y}\right)$ \\
\hline
\end{tabular}

Populasi dalam penelitian ini seluruh siswa kelas V SD N 1 Sukarame yang berjumlah 55 siswa yang tersebar dalam dua kelas. Pengambilan sampel dalam penelitian ini menggunakan teknik purposive sampling (pengambilan sampel dengan pertimbangan tertentu), sehingga didapatkan sampel berjumlah 29 siswa.
Teknik pengumpulan data yang digunakan pada penelitian ini yaitu data kuantitatif. Instrumen penelitian yang digunakan berbentuk tes. Tes yang diberikan berupa butir soal uraian (essay) untuk mengukur kemampuan komunikasi matematis peserta didik. Kemampuan komunikasi matematis ini dapat diukur sesuai dengan pedoman penskoran tes pada tabel berikut:

Tabel 3.

Pedoman Penskoran Tes Kemampuan Komunikasi Matematis

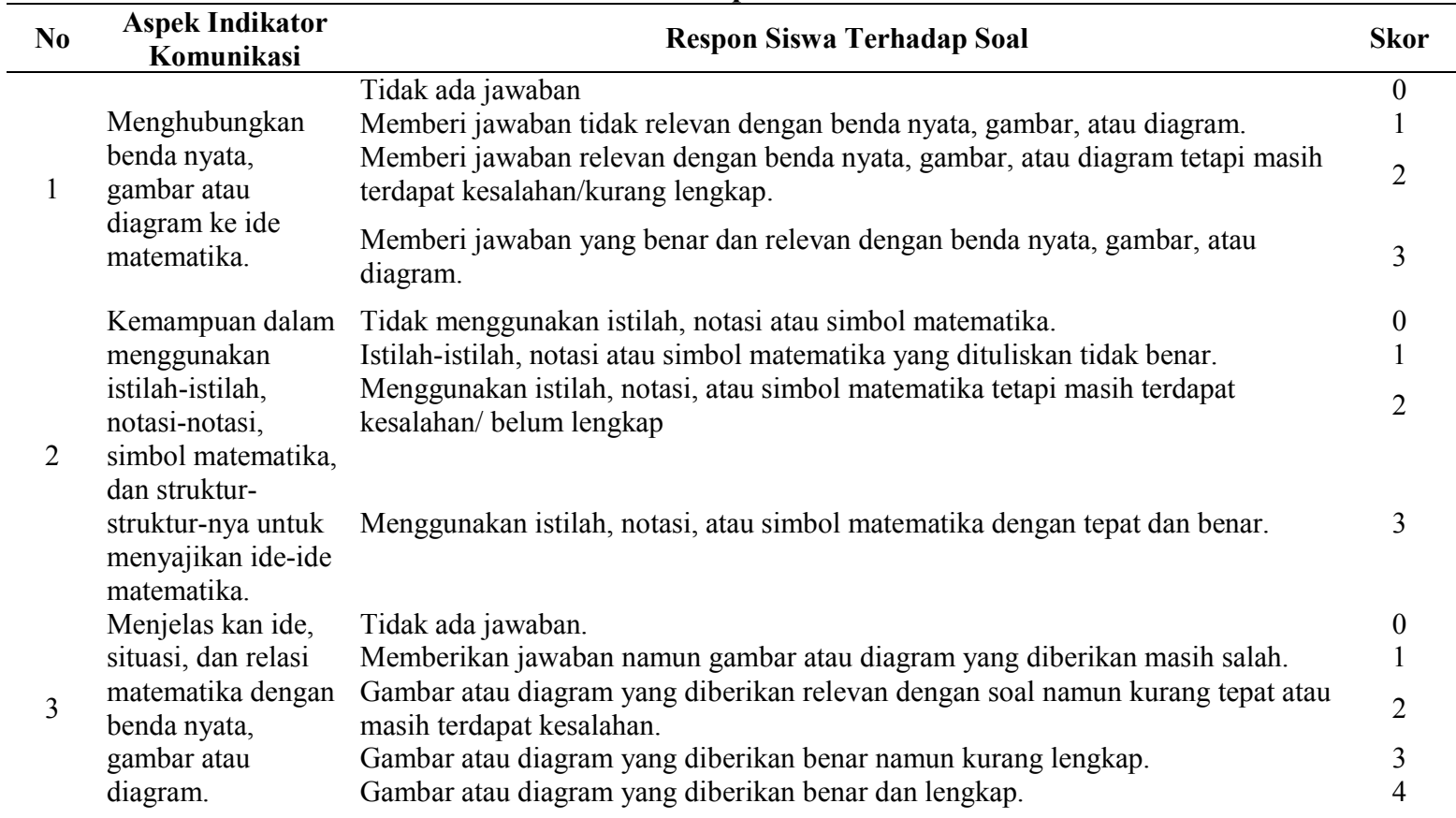


PENGARUH HYPNOTEACHING DALAM CONTEXTUAL TEACHING AND LEARNING ... REFLEKSI EDUKATIKA : Jurnal Ilmiah Kependidikan, Nomor 9, Volume 1, Desember 2018, hlm. 46-55

\begin{tabular}{|c|c|c|c|}
\hline No & $\begin{array}{l}\text { Aspek Indikator } \\
\text { Komunikasi }\end{array}$ & Respon Siswa Terhadap Soal & Skor \\
\hline \multirow{5}{*}{4} & \multirow{5}{*}{$\begin{array}{l}\text { Menarik } \\
\text { kesimpulan, } \\
\text { menyusun bukti, } \\
\text { memberi alasan } \\
\text { atau bukti terhadap } \\
\text { beberapa solusi. }\end{array}$} & Tidak ada jawaban. & 0 \\
\hline & & Kesimpulan/jawaban salah namun memberikan bukti atau alasan terhadap & 1 \\
\hline & & $\begin{array}{l}\text { Kesimpulan/jawaban benar namun tidak memberikan bukti atau alasan terhadap } \\
\text { jawaban. }\end{array}$ & 2 \\
\hline & & $\begin{array}{l}\text { Kesimpulan/jawaban benar, ada bagian penting dari bukti atau alasan yang belum } \\
\text { selesai atau terdapat kesalahan/belum lengkap. }\end{array}$ & 3 \\
\hline & & Kesimpulan/jawaban benar, bukti atau alas an benar, jelas, dan tanpa kesalahan. & 4 \\
\hline
\end{tabular}

Uji Hipotesis yang digunakan dalam penelitian ini yaitu uji Analisis Varians (Anava) atau Analysis of Variance (Anova), karena dalam penelitian ini hanya menggunakan satu pembanding (variabel bebas) untuk tiga kelompok sampel dengan perlakuan yang berbeda setiap kelompoknya. Pengujian hipotesis yang akan dilakukan peneliti adalah menggunakan uji Anava satu jalan dengan sel sama.

\section{HASIL DAN PEMBAHASAN}

Pengambilan data dilakukan setelah proses pembelajaran pada materi Bangun Datar submateri Persegi Panjang dan Persegi. Setelah data dari setiap variabel terkumpul, selanjutnya melakukan pengujian hipotesis penelitian. Data tentang komunikasi matematis peserta didik pada materi Bangun Datar sub materi Persegi Panjang dan Persegi yang sudah diperoleh, selanjutnya dapat dicari nilai tertinggi $\left(X_{\text {maks }}\right)$ dan nilai terendah $\left(X_{\text {min }}\right)$. Kemudian dicari ukuran tendensi sentralnya yang meliputi rataan $(\bar{X})$, median $\left(M_{e}\right)$, modus $\left(M_{o}\right)$, dan ukuran variasi kelompok diantaranya jangkauan $(R)$ dan simpangan baku $(S)$ pada kelas eksperimen maupun kelas kontrolnya yang dirangkum dalam tabel berikut ini

Tabel 4

Deskripsi Data Skor Amatan

\begin{tabular}{|c|c|c|c|c|c|c|c|c|}
\hline \multirow[t]{2}{*}{ Kelompok } & \multirow[t]{2}{*}{$N$} & \multirow[t]{2}{*}{$X_{\text {maksimal }}$} & \multirow[t]{2}{*}{$X_{\text {minimal }}$} & \multicolumn{3}{|c|}{ Ukuran Tendensi Sentral } & \multicolumn{2}{|c|}{$\begin{array}{c}\text { Ukuran Variasi } \\
\text { Kelompok }\end{array}$} \\
\hline & & & & Rata-rata & $\mathbf{M}_{\mathbf{0}}$ & $\mathbf{M}_{\mathbf{e}}$ & $\mathbf{R}$ & $\mathbf{S}$ \\
\hline $\begin{array}{c}\text { Hypno CTL } \\
\text { (Eksperimen) }\end{array}$ & 29 & 89 & 47 & 70,931 & 72 & 72 & 42 & 11,498 \\
\hline $\begin{array}{c}\text { Hypno Konven } \\
\text { (Kontrol) }\end{array}$ & 29 & 83 & 38 & 54,276 & $\begin{array}{c}50 \text { dan } \\
52\end{array}$ & 52 & 45 & 10,770 \\
\hline Konven (Kontrol) & 29 & 80 & 26 & 52,069 & 50 & 50 & 54 & 15,289 \\
\hline
\end{tabular}

Berdasarkan Tabel 4 tersebut, diperoleh hasil tes kemampuan komunikasi matematis dengan nilai tertinggi $\left(X_{\text {maks }}\right) 89$ pada kelas eksperimen, nilai tertinggi 83 pada kelas kontrol peneliti, dan nilai tertinggi 80 pada kelas kontrol guru. Pada kelas eksperimen memperoleh nilai terendah $\left(X_{\min }\right)$ yaitu 47 , kelas kontrol peneliti memperoleh nilai terendah 38 dan kelas kontrol guru memperoleh nilai terendah 26. Hal ini berarti, nilai yang diperoleh kelas eksperimen baik nilai tertinggi maupun nilai terendah lebih besar dari pada kelompok kontrol peneliti atau kelompok kontrol guru. Selanjutnya, pada ukuran tendensi sentral meliputi nilai rerata untuk kelompok eksperimen diperoleh nilai rataratanya 70,931, pada kelompok kontrol peneliti diperoleh nilai rata-rata 54,276, dan pada kelas kontrol guru diperoleh nilai rata-rata 52,069.
Sementara itu, nilai tengah hasil tes kemampuan komunikasi matematis kelompok eksperimen yaitu 72, pada kelompok kontrol peneliti adalah 52, dan pada kelompok kontrol guru adalah 50. Jika dicari selisih atau perbandingan berdasarkan nilai rata-rata hasil tes kemampuan komunikasi matematis antara eksperimen dengan kontrol (70,931 - 54,276= 16,655) maka diperoleh selisih perbedaan nilai cenderung lebih tinggi. Namun, jika dicari selisih perbedaan berdasarkan nilai rerata hasil tes kemampuan komunikasi matematis antara kontrol peneliti dengan kontrol guru (54,276 $52,069=2,207)$, maka diperoleh selisih perbedaan nilai cenderung lebih rendah.

Modus atau nilai hasil tes kemampuan komunikasi matematis yang paling banyak diperoleh peserta didik pada kelas eksperimen 
adalah 72, pada kelas kontrol peneliti adalah 50 dan 52, dan pada kelas kontrol guru adalah 50. Sementara itu, ukuran dispersi (penyebaran) kelompok yang meliputi jangkauan atau rentang yaitu jarak antara nilai tertinggi dan terendah kelas eksperimen adalah 42, kelas kontrol peneliti 45, dan kelas kontrol guru 54. Simpangan baku kelas eksperimen diperoleh 11,498, kelas kontrol peneliti diperoleh 10,770 dan kelas kontrol guru diperoleh simpangan baku 15,289. Berdasarkan selisih nilai yang telah di uraikan, hal ini berarti bahwa rerata kemampuan komunikasi matematis peserta didik kelompok

eksperimen lebih baik dari pada kelompok kontrol peneliti maupun guru.

\section{Uji Analisis Varians (Anava)}

Uji hipotesis yang digunakan pada penelitian ini yaitu uji Analisis Varians (Anava) untuk menguji ada atau tidaknya pengaruh pada beberapa perlakuan (penerapan metode pembelajaran) terhadap kemampuan komunikasi matematis peserta didik. Hasil uji Analisis Varians (Anava) disajikan pada tabel 5 berikut ini:

Tabel 5

Ringkasan ANAVA Satu Jalan Sel Sama

\begin{tabular}{ccccccc}
\hline Sumber & $\begin{array}{c}\text { Jumlah } \\
\text { Kuadrat (JK) }\end{array}$ & $\begin{array}{c}\text { Derajat } \\
\text { Kebebasan } \\
\text { (dk) }\end{array}$ & $\begin{array}{c}\text { Rataan } \\
\text { Kuadrat } \\
\text { (RK) }\end{array}$ & $\mathrm{F}_{\text {obs }}$ & $\mathrm{F}_{\text {tabel }}$ & $\boldsymbol{\alpha}$ \\
\hline Metode (A) & 6167,747 & 2 & 3083,874 & 19,195 & 3,105 & 0,05 \\
Galat (G) & 13495,517 & 84 & 160,661 & & \\
Total (T) & 19663,264 & 86 & & & \\
\hline
\end{tabular}

Berdasarkan perhitungan pengujian analisis varians diperoleh hasil $\mathrm{F}_{\mathrm{obs}}=19,195$ dan $\mathrm{F}_{\text {tabel }}=3,105$. Hasil perhitungan telah menunjukkan bahwa $\mathrm{F}_{\text {obs }}>\mathrm{F}_{\text {tabel }}$ ini berarti nilai $\mathrm{F}_{\text {obs }}$ yang diperoleh lebih besar daripada nilai $\mathrm{F}_{\text {tabel }}$, maka keputusan ujinya $\mathrm{H}_{0}$ ditolak. Data ini menunjukan bahwa, rerata kemampuan komunikasi matematis peserta didik dengan tiga perlakuan yaitu pembelajaran menggunakan metode Hypnoteaching CTL yang diterapkan oleh peneliti, pembelajaran menggunakan metode Hypnoteaching konvensional yang diterapkan oleh peneliti, dan pembelajaran konvensional yang diterapkan guru, berpengaruh signifikan terhadap kemampuan komunikasi peserta didik kelas V SDN 1 Sukarame Bandar Lampung Tahun Ajaran 2015/2016. Karena keputusan uji Anava $\mathrm{H}_{0}$ ditolak, maka dapat dilakukan uji Komparasi Ganda.

\section{Uji Komparasi Ganda}

Pengujian hipotesis tolak $\mathrm{H}_{0}$, maka akan dilakukan uji Anava lanjut (komparasi ganda). Hal ini dilakukan untuk mengetahui dari ketiga metode pembelajaran tersebut, manakah yang lebih baik untuk kemampuan komunikasi matematis peserta didik. Dalam penelitian ini uji lanjut pasca anava (komprasi ganda) menggunakan metode Schefee', dengan kriteria pengujian yaitu, jika $\mathrm{F}_{\mathrm{i}-\mathrm{j}}>(\mathrm{k}-1) \mathrm{F}_{\text {tabel }}$, maka $\mathrm{H}_{0}$ ditolak, jika $F_{i-j} \in D K$ dan sebaliknya, jika $F_{i-j}<$ (k-1) $\mathrm{F}_{\text {tabel }}$, maka $\mathrm{H}_{0}$ diterima. Pada taraf signifikansi $\alpha=5 \%$. Pasangan komparasi rataan pada pengujian ini adalah sebagai berikut:

Tabel 6

Pasangan Komparasi Rataan

\begin{tabular}{ccc}
\hline Komparasi & $\mathbf{H}_{\mathbf{0}}$ & $\mathbf{H}_{\mathbf{1}}$ \\
\hline$\mu_{1}$ vs $\mu_{2}$ & $\mu_{1}=\mu_{2}$ & $\mu_{1} \neq \mu_{2}$ \\
$\mu_{2}$ vs $\mu_{3}$ & $\mu_{2}=\mu_{3}$ & $\mu_{2} \neq \mu_{3}$ \\
$\mu_{1}$ vs $\mu_{3}$ & $\mu_{1}=\mu_{3}$ & $\mu_{1} \neq \mu_{3}$ \\
\hline
\end{tabular}

Keterangan:

$\mu_{1}$ : rerata kemampuan komunikasi matematis peserta didik yang mendapat penerapan metode pembelajaran Hypnoteaching dalam CTL.

$\mu_{2}$ : rerata kemampuan komunikasi matematis peserta didik yang mendapat penerapan metode pembelajaran Hypnoteaching konvensional.

$\mu_{3}$ : rerata kemampuan komunikasi matematis peserta didik yang mendapat penerapan metode pembelajaran konvensional.

Rangkuman dari hasil uji komparasi ganda diujikan pada tabel dibawah ini: 
Tabel 7

Rangkuman Hasil Uji Komparasi Ganda

\begin{tabular}{ccccccc}
\hline Komparasi & $\left(\overline{\boldsymbol{X}_{\boldsymbol{\imath}}}-\overline{\boldsymbol{X}_{\boldsymbol{j}}}\right)^{\mathbf{2}}$ & $\left(\frac{\mathbf{1}}{\boldsymbol{n}_{\boldsymbol{d}}}+\frac{\mathbf{1}}{\boldsymbol{n}_{\boldsymbol{j}}}\right)$ & $\boldsymbol{R} \boldsymbol{K} \boldsymbol{G}$ & $\boldsymbol{F}_{\text {obs }}$ & Kritik & Hasil Uji \\
\hline$\mu_{1}$ vs $\mu_{2}$ & 277,389 & 0,069 & 160,661 & 25,022 & 6,21 & $\mathrm{H}_{0}$ ditolak \\
$\mu_{2}$ vs $\mu_{3}$ & 4,871 & 0,069 & 160,661 & 0,439 & 6,21 & $\mathrm{H}_{0}$ diterima \\
$\mu_{1}$ vs $\mu_{3}$ & 355,775 & 0,069 & 160,661 & 32,09 & 6,21 & $\mathrm{H}_{0}$ ditolak \\
\hline
\end{tabular}

Berdasarkan hasil uji komparasi ganda dalam Tabel 7 di atas, dapat diketahui bahwa perbedaan yang signifikan terjadi pada komparasi $\mu_{1}$ vs $\mu_{2}$ dan $\mu_{1}$ vs $\mu_{3}$. Maka dapat disimpulkan bahwa:

1. Terdapat perbedaan kemampuan komunikasi matematis antara peserta didik yang mendapat penerapan metode Hypnoteaching CTL dengan yang mendapat penerapan metode Hypnoteaching Konvensional. Karena rerata kemampuan komunikasi matematis yang mendapat penerapan metode Hypnoteaching CTL lebih tinggi dibandingkan peserta didik yang mendapat penerapan metode Hypnoteaching Konvensional, yaitu 70,931 > 54,276 maka dapat disimpulkan bahwa metode Hypnoteaching CTL lebih baik daripada metode Hypnoteaching Konvensional.

2. Tidak terdapat perbedaan kemampuan komunikasi matematis antara peserta didik yang mendapat penerapan metode Hypnoteaching Konvensional dengan yang mendapat penerapan metode Konvensional. Meskipun rerata kemampuan komunikasi matematis yang mendapat penerapan metode Hypnoteaching konvensional lebih tinggi dibandingkan peserta didik yang mendapat penerapan metode Konvensional, yaitu $54,276>52,069$. Namun, beda rerata tersebut tidak signifikan. Artinya dalam hal ini tidak ada perlakuan yang lebih antara metode pembelajaran Hypnoteaching Konvensional dengan metode Konvensional, kemampuan komunikasi matematis antara peserta didik melalui penerapan metode Hypnoteaching Konvensional sama baiknya dengan peserta didik yang mendapat penerapan metode Konvensional.

3. Terdapat perbedaan kemampuan komunikasi matematis antara peserta didik menggunakan penerapan metode Hypnoteaching CTL denganyang mendapat penerapan metode Konvensional. Karena rerata kemampuan komunikasi matematis yang mendapat penerapan metode Hypnoteaching CTL lebih tinggi daripada peserta didik yang mendapat penerapan metode Konvensional, yaitu 70,931> 52,069 maka dapat disimpulkan bahwa metode Hypnoteaching CTL lebih baik daripada metode Konvensional.

Penerapan metode Hypnoteaching yang kombinasikan dengan menggunakan pendekatan CTL pada kelas eksperimen memberikan hasil tes kemampun komunikasi matematis lebih besar dibandingkan hasil tes kemampun komunikasi matematis pada kelas kontrol peneliti yang menerapkan metode Hypnoteaching Konvensional. Hal ini berarti metode Hypnoteaching berpengaruh terhadap hasil belajar peserta didik jika metode Hypnoteaching dapat dikombinasikan dengan metode pembelajaran lainnya yang menunjang kegiatan pembelajaran. Hasil penelitian ini sesuai dengan penelitian yang telah dilakukan oleh Priyono (2015), yaitu penggunaan metode hypnoteaching dapat meningkatkan proses dan hasil belajar tentang pecahan siswa kelas V SD Negeri Benerwetan Tahun Ajaran 2014/2015.

\section{SIMPULAN}

Berdasarkan hasil penelitian yang telah dilakukan, maka disimpulkan bahwa terdapat pengaruh pada hasil kemampuan komunikasi matematis peserta didik kelas $\mathrm{V}$ SD $\mathrm{N} 1$ Sukarame Bandar Lampung pada pokok materi Persegi Panjang dan Persegi yang menggunakan metode pembelajaran Hypnoteaching dalam Contextual Teaching and Learning (CTL) Selanjutnya, setelah dilakukan uji komparansi ganda disimpulkan bahwa metode pembelajaran yang lebih baik untuk meningkatkan kemampuan komunikasi matematis peserta didik adalah metode pembelajaran Hypnoteaching dalam CTL diantara metode pembelajaran Hypnoteaching Konvensional dan metode Konvensional. Selain itu, rekomendasi dari penelitian ini adalah Metode pembelajaran Hypnoteaching dalam Contextual Teaching and Learning (CTL) diharapkan dapat disosialisasikan sebagai alternatif pembelajaran dalam pelajaran matematika; peserta didik sebaiknya tidak perlu ragu dan takut untuk mengeksplorasikan ide-ide 
matematisnya untuk menyelesaikan berbagai permasalahan matematika; dan pada pembelajaran matematika, perlu adanya pemilihan metode pembelajaran yang bervariasi dan disesuaikan dengan materi pembelajaran.

\section{DAFTAR PUSTAKA}

Asteria, Prima Vidya., dkk. 2017. Penerapan Metode Hypnoteaching Dalam Pembelajaran Bermain Peran Siswa Kelas V SDN Lidah Kulon IV Surabaya. Jurnal Pendidikan (teori dan Praktik) 2 (2).

Hasbullah dan Rahmawati, Eka Yuni. 2015. Pengaruh Penerapan Metode Hypnoteaching Terhadap Motivasi Belajar Mahasiswa Universitas Indraprasta PGRI. Jurnal Formatif (5): 83-90.

Hodiyanto. 2017. Kemampuan Matematis Dalam Pembelajaran Matematika. Jurnal AdMathEdu, 7 (1).

Irwandi. 2015. Proses Pembelajaran Dengan Metode Hypnoteaching. Jurnal Al-Irsyad. 5 (1).

Jackson., P.W. 1992. Handbook of Research on Curriculum. New York : A Project of American Educational Research Assosiation.

Kasmaja, Hadi. 2016. Efektivitas Implementasi Metode Hypnoteaching Untuk Meningkatkan Motivasi dan Hasil Belajar Matematika Pada Siswa SMP Negeri. Journal of EST, 2 (1). Hal 33-45.

Khakim, dkk. 2015. Penerapan Model Contextual Teaching and Learning Melalui Pemanfaatan Lingkungan Sekitar Untuk Meningkatkan Hasil Belajar IPA Kelas V SD 1 Peganjaran Kudus. Jurnal Refleksi Edukatika, 5 (1).

Latif, Rodli A. 2013. Pengaruh Metode Hypnoteaching dalam Contextual Teaching and Learning (CTL) terhadap Kemampuan Komunikasi dan Analisis Kritis Siswa Kelas XI IPA di SMA Negeri 5 Yogyakarta (Skripsi). Yogyakarta: Program Sarjana Universitas Islam Negeri Sunan Kalijaga.
Nasution, Andi Hakim. 2011. Hypnosis in teaching : Cara Dahsyat Mendidik dan Mengajar. Jakarta : Visi Media.

Priyono, Among., dkk. 2015. Penggunaan Metode Hypnoteaching Dalam Peningkatan Pembelajaran Matematika Tentang Pecahan Pada Siswa Kelas V SD Negeri Benerwetan Tahun Ajaran 2014/2015. Jurnal Kalam Cendekia, 5 (5).1: 420-425.

Rahmawatiningrum, L. Efektivitas Penggunaan metode Hypnoteaching dalam Pembelajaran Matematika Kelas IV SDIH Soebandi Kecamatan Bawen Kabupaten Semarang Tahun Pelajaran 2011/2012 (Skripsi). Yogyakarta: Universitas Kristen Satya Wacana.

Salami. 2017. Hypnotic Teacher dan Hypnoteaching. Jurnal Ar-Raniry, III (1).

Sugiyono. 2011. Metode Penelitian Pendidikan Pendekatan Kuantitatif, Kualitatif, $R \& D$ Cet ke-13. Bandung: Alfabeta.

Suprijono, A. 2009. Cooperatif Learning Teori dan Aplikasi. Yogyakarta: Pustaka Pelajar.

Susanto, A. 2013. Teori Belajar dan Pembelajaran di Sekolah Dasar. Jakarta: Kencana Prenada.

Trianto. 2008. Mendesain Pembelajaran Kontekstual (Contextual Teaching And Learning) Di Kelas. Jakarta: Cerdas Pustaka Publisher.

Yustisia, N. 2012. Hypnoteaching (Seni Ajar Mengeksplorasi Otak Peserta Didik. Yogyakarta: Ar-Ruzz Media. 